\title{
ARCHEOLOGIA, DZIEDZICTWO ARCHEOLOGICZNE I ICH SPOŁECZNE ZNACZENIE W OCZACH WSPÓŁCZESNYCH POLAKÓW
}

\author{
ARCHAEOLOGY, ARCHAEOLOGICAL HERITAGE \\ AND THEIR SOCIAL SIGNIFICANCE AMONG \\ CONTEMPORARY POLES
}

\author{
Kornelia Kajda \\ Instytut Archeologii. Uniwersytet im. Adama Mickiewicza w Poznaniu \\ ul. Umultowska 89D, 61-614 Poznań, Polska \\ korkajda@amu.edu.pl \\ Michat Pawleta \\ Instytut Archeologii. Uniwersytet im. Adama Mickiewicza w Poznaniu \\ ul. Umultowska 89D, 61-614 Poznań, Polska \\ mpawleta@amu.edu.pl

\section{Arkadiusz Marciniak} \\ Instytut Archeologii. Uniwersytet im. Adama Mickiewicza w Poznaniu \\ ul. Umultowska 89D, 61-614 Poznań, Polska \\ arekmar@amu.edu.pl
}

\begin{abstract}
The article explores the issues connected to the social role of archaeology and its meaning among the public. In the paper we analyze the European survey conducted by Harris Interactive in 9 European countries (Poland, Greece, Italy, France, Sweden, UK, Holland, Germany, Spain) with a special account on its results in Poland. The results of the survey present that archaeology is a scientific discipline of special interest among Poles and that they appreciate and need a contact and cooperation with archaeologists which would enable society to understand more the importance of our own past.
\end{abstract}

KEY WORDS: archaeology in the society, past, NEARCH project, European survey, Poles 
Archeologia jest nauką, która ma ogromny potencjał i możliwości w kontekście współpracy ze społeczeństwem. Ów potencjał wynika nie tylko z tego, że tematy podejmowane przez archeologów cieszą się zainteresowaniem społecznym, ale jest on także rezultatem działan samych archeologów, którzy w ostatnich latach podejmują wiele wysiłku, aby ich osiągnięcia były publicznie rozpoznawane (por. Deskur, 2009; Chowaniec, 2010; Chowaniec, Więckowski, 2012; Zalewska, 2013; Czopek, Górski, 2016; Kajda, Kostyrko, 2016). Jednak aby działania badaczy były odpowiednio projektowane, muszą być one także inspirowane wiedzą o tym, czego w rzeczywistości społeczeństwo od nich oczekuje, w jaki sposób postrzega archeologię dziś, jak również, jaką widzi dla niej rolę w przyszłości. Badania nad społecznym znaczeniem i rozumieniem archeologii zostały niedawno podjęte na skalę ogólnoeuropejską, w tym także w kontekście polskim. Przeprowadzono je w ramach europejskiego projektu badawczego „NEARCH: New Scenarios for a CommunityInvolved Archaeology" prowadzonego przez francuski INRAP we współpracy z wieloma ośrodkami naukowymi, w tym Instytutem Archeologii UAM.

\section{BADANIA NAD SPOŁECZNYM ZNACZENIEM ARCHEOLOGII W POLSCE}

W ramach polskiej archeologii temat dotyczący społecznego znaczenia archeologii i wyników jej prac badawczych był już podejmowany (Kobyliński, Paczuska, 2007; Kubiatowski, 2015; Pawleta, 2016). Badania polskich archeologów w tym zakresie skupiały się jednak na niewielkich grupach respondentów, a zwłaszcza na lokalnych społecznościach, w miejscach, w których prowadzili oni swoje prace badawcze. Starali się oni określić wartości przypisywane przez ludzi dziedzictwu archeologicznemu oraz postrzeganie przez nich samej archeologii. Dość interesujące $\mathrm{z}$ tej perspektywy były badania przeprowadzone w ramach projektu pt. „Zaangażowanie społeczności lokalnych w ochronę dziedzictwa archeologicznego" kierowanego przez Małgorzatę $\mathrm{Kot}^{2}$. Ze względu jednak na brak szczegółowych informacji dotyczących ilości przeprowadzonych wywiadów oraz skali ich zasięgu, trudno odnieść się bardziej szczegółowo do ich wyników. Mimo to wskazuje się w tym wypadku na istotną rolę samych archeologów w procesie popularyzacji wiedzy o tej dyscyplinie. Zdaniem M. Kot archeolodzy nadal podchodzą do społeczności lokalnych w sposób paternalistyczny, co może źle wpływać na ich odbiór przez ludzi. Dlatego niezwykle ważna wydaje się konieczność kształcenia już na etapie studiów młodych adeptów archeologii w zakresie sposobów promocji i popularyzacji zdoby-

\footnotetext{
${ }^{1}$ Zob. http://www.nearch.eu/ [dostęp 1.12.2017].

${ }^{2}$ Zob: http://naukawpolsce.pap.pl/aktualnosci/news,404320,badanie-dziedzictwo-archeologiczne-na lezy-do-urzednikow-i-naukowcow.html [dostęp 1.12.2017].
} 
tej wiedzy i dyscypliny naukowej oraz uczyć ich nawiązywania relacji z lokalnymi społecznościami i zachęcać do współpracy z nimi, aby ludzie poczuli się współodpowiedzialni za dziedzictwo archeologiczne. Podobne wyniki uzyskali Kornelia Kajda oraz Mikołaj Kostyrko (2016), którzy razem ze studentami przeprowadzali wywiady i ankiety z mieszkańcami wsi Bieniów i Biedrzychowice Dolne w województwie lubuskim, na granicy których to miejscowości prowadzili nieinwazyjne badania archeologiczne. Wyniki przeprowadzonych wywiadów wykazały, że ludzie nadal silnie kojarzą archeologię z jej podstawową metodą badawczą - wykopaliskami. Zdaniem rozmówców to właśnie ta metoda badawcza stanowi o odrębności archeologii w ramach studiów historycznych i humanistycznych. Z kolei badania w tym zakresie przeprowadzone przez Annę Kozioł, Małgorzatę Trelkę i Patrycję Florjanowicz (2013) skupiły się nad znaczeniem dziedzictwa kulturowego jako takiego, a także jego wpływu na rozwój społeczny i gospodarczy. Uczestnicy badania potwierdzili, że dziedzictwo kulturowe jest wartościowym zasobem oddziałującym na rozwój społeczny i gospodarczy, że pełni ono ważną rolę społeczną oraz że obecność zabytków pozytywnie wpływa na jakość życia.

\section{PROJEKT NEARCH - OGÓLNOEUROPEJSKIE BADANIE SPOŁECZNEGO ZNACZENIA ARCHEOLOGII}

Europejski project NEARCH (New Scenarios for a Community-Involved Archaeology) realizowany jest od 2013 roku przez partnerów z 9 europejskich krajów (Francja, Polska, Hiszpania, Włochy, Grecja, Holandia, Wielka Brytania, Szwecja, Niemcy) i kierowany jest przez Narodowy Instytut Badań Archeologii Ratunkowej we Francji (French National Institute for Preventive Archaeological Research Inrap). W ramach pięciu lat realizacji projektu jego ideą przewodnią jest skupienie się na różnych formach uczestnictwa społeczeństwa w działaniach archeologicznych, a także wypracowanie takich sposobów współpracy między różnymi środowiskami, aby stworzyć nową platformę porozumienia i realizacji projektów związanych z archeologią i szeroko pojętym dziedzictwem kulturowym. Ważną część projektu stanowi także badanie wpływu dziedzictwa archeologicznego i archeologii na rozwój wybranych regionów i poprawę jakości życia mieszkańców dzięki dostępowi do zasobów kulturowych.

W ramach jednego z zadań realizowanych w ramach projektu NEARCH przeprowadzono wywiady w 9 krajach partnerskich, które dotyczyły społecznego znaczenia i rozumienia archeologii. W każdym kraju zebrano 500 kwestionariuszy (w Grecji 516), których wyniki wykorzystano następnie do interpretacji badanego zagadnienia. Szczegółowe wyniki badań i ich interpretację na skalę międzynarodową zostały przedstawione w artykule ,Archaeology, Heritage, and Social Value: Public Perspectives on European Archaeology" (Kajda i in., 2017), natomiast 
w niniejszym tekście skoncentrujemy się na wynikach badań przeprowadzonych na respondentach pochodzących z Polski, aby ukazać społeczne znaczenie archeologii i perspektywy jej rozwoju, które wynikają z poniższych analiz ${ }^{3}$.

Badanie składało się z 28 pytań, które zostały sprofilowane tak, aby odpowiadały różnicom w poszczególnych krajach, przy interpretacji poszczególnych form dziedzictwa archeologicznego. Pytania miały zarówno formę otwartą, jak i zamkniętą, a interpretację odpowiedzi na pytania przeprowadzono zgodnie z kluczem ustalonym przez firmę Harris Interactive, która przeprowadziła badania.

\section{ANALIZA I INTERPRETACJA WYNIKÓW BADAŃ W POLSCE}

W niniejszym tekście zdecydowaliśmy się poddać interpretacji jedynie wybrane wątki wynikające z badań kwestionariuszowych przeprowadzonych wśród respondentów z Polski. Nasze zainteresowanie skierowaliśmy głównie na trzy aspekty, mianowicie: społeczne rozumienie archeologii, społeczne zainteresowanie archeologią, a także społeczne rozumienie i zainteresowanie specyficznym rodzajem archeologii, mianowicie ,archeologią ratowniczą" (ang. preventive archaeology, rescue archaeology) ${ }^{4}$. Mimo że badanie poruszało więcej aspektów odnoszących się do znaczenia archeologii dla społeczeństwa, w celu zachowania klarowności rezultatów badania i ich interpretacji z perspektywy społecznej w artykule skupiamy się jedynie na trzech wymienionych powyżej kwestiach.

\section{ROZUMIENIE ARCHEOLOGII I JEJ ROLA}

Do interpretacji zagadnień związanych ze społecznym rozumieniem archeologii posłużą nam odpowiedzi na pytania numer 1, 2, 4 (pytanie numer 3 było jedynie dopełnieniem pytania $\mathrm{nr} 2$, zatem nie będzie ono analizowane w artykule). Pierwsze z nich brzmiało: „Czym jest archeologia? Jakbyś ją zdefiniował/a?”. 61\% respondentów określiło archeologię na podstawie jej metody badawczej i uznało, że archeologia to wykopywanie/wykopaliska różnych obiektów, artefaktów, pozostałości czy szczątków ludzkich (podobnie jak w badaniach: Kajda, Kostyrko, 2016). Zaskakujące jest to, że wynik ten jest dużo wyższy niż średnia europejska dla odpowiedzi na to pytanie, która wynosiła 37\%. W innych krajach europejskich archeologia jest bardziej łączona z samym studiowaniem/badaniem przeszłości, w Polsce natomiast

\footnotetext{
${ }^{3}$ Wyniki ankiet są dostępne online: http://dx.doi.org/10.5284/1041589

${ }^{4}$ Termin ten odnosi się to do ratowniczych badań archeologicznych, prowadzonych w celu odkrycia, rozpoznania, zbadania i zdokumentowania obiektów i stanowisk archeologicznych na obszarach zagrożonych zniszczeniem. Wiążą się one zwykle z inwestycjami budowlanymi oraz pracami ziemnymi, mogą jednak też wynikać z zagrożeń spowodowanych gospodarką rolniczą czy czynnikami naturalnymi.
} 
to właśnie wykopaliska stanowią główny element kojarzący się ludziom z tą nauką. Archeologię jako badanie przeszłości definiuje 56\% respondentów, co także wskazuje na to, że według społeczeństwa archeologia jest dziedziną ściśle związaną ze zdobywaniem wiedzy na temat przeszłości.

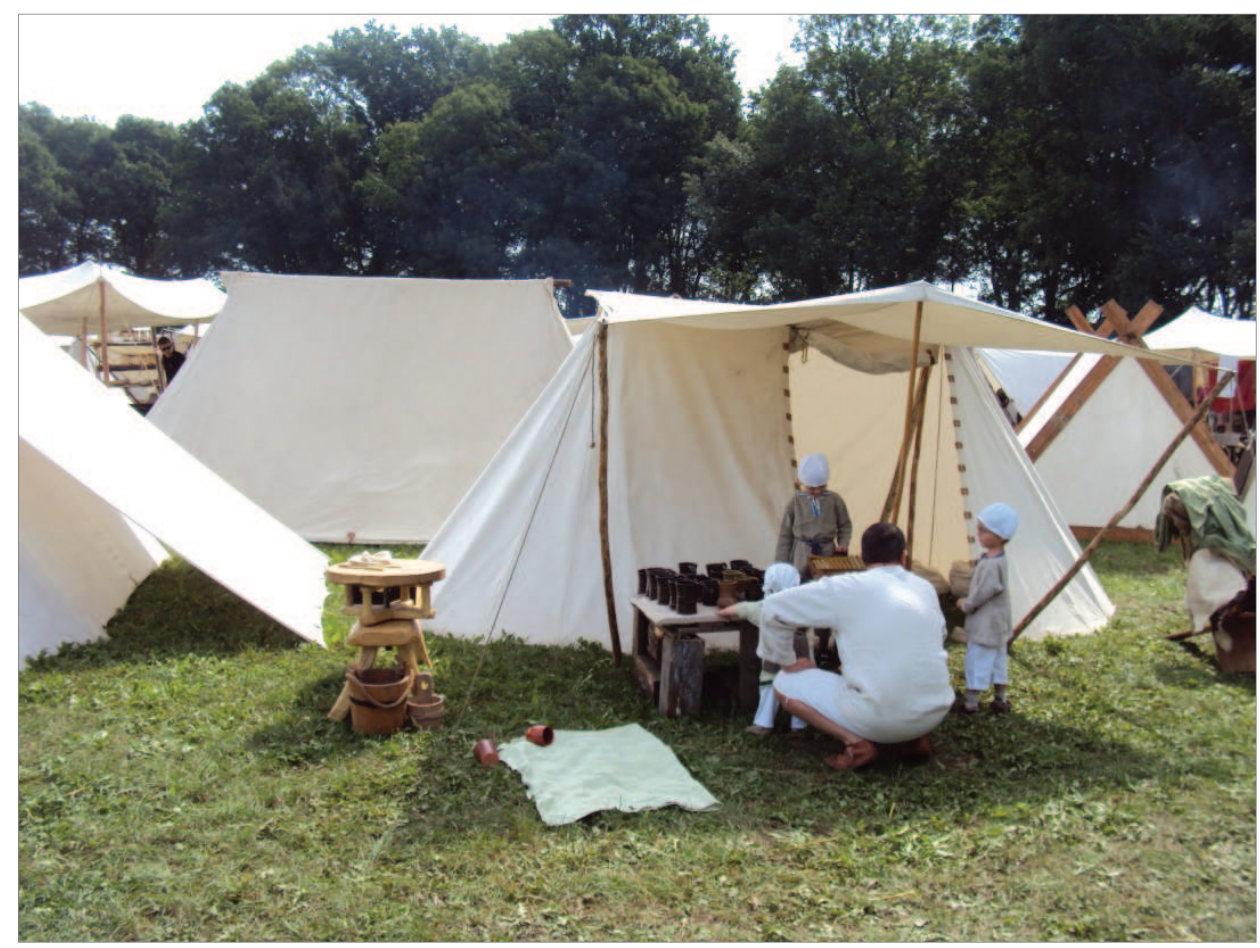

Ryc. 1. Nauczanie dzieci o przeszłości podczas jednego z archeologicznych festiwali odbywających się w Polsce (fot. Dawid Kobiałka)

Fig. 1. Learning children about the past during one of the archaeological festivals in Poland (photo by Dawid Kobiałka)

Pytania drugie i czwarte dotyczyły roli archeologii w teraźniejszości. W pytaniu drugim respondenci mieli odnieść się do tego, dlaczego ich zdaniem archeologia może mieć znaczenie w dzisiejszych czasach. Przeważająca większość udzielonych odpowiedzi $(93 \%)^{5}$ wskazywała na to, że archeologia jest potrzebna, ponieważ pomaga nam zrozumieć nasze pochodzenie, przeszłość i korzenie naszej cywilizacji. O wiele mniej liczne odpowiedzi (zaledwie 4\%) dotyczyły tego, że archeologia może także pomóc w zrozumieniu teraźniejszości, jak i w przewidywaniu przyszłości

\footnotetext{
${ }^{5}$ Średnia europejska odpowiedzi dla tego pytania wynosiła $75 \%$.
} 
i przygotowaniu się na to, co nam ona przyniesie. Wszystkie odpowiedzi w tym zakresie w znacznym stopniu pokrywały się ze średnią europejską, choć Polacy dużo częściej wskazywali na znaczenie archeologii w dochodzeniu do wiedzy o naszej przeszłości. Z kolei w pytaniu 4 respondenci mieli wskazać na trzy główne role, jakie mogą być przypisywane archeologii. W tym przypadku ponownie najistotniejsze okazało się dochodzenie do własnej przeszłości i poznawanie historii Polski $(57 \%)^{6}$. Dopiero kolejne odpowiedzi wskazywały na znaczenie archeologii w badaniu i ochronie dziedzictwa kulturowego oraz przekazywaniu historii młodszym generacjom. Polacy zaznaczali także ważną rolę archeologii w zrozumieniu przeszłości, aby przygotować się do nadchodzących wydarzeń w przyszłości $(40 \%)$, a także w lepszym zrozumieniu własnego miejsca na świecie (30\%). Wśród Polaków odpowiedzi te pojawiały się rzadziej niż w innych krajach europejskich, gdzie średnia takiej odpowiedzi wynosiła odpowiednio 46\% i 40\%. Oznacza to, że archeolodzy i inne osoby zajmujące się badaniami nad przeszłością w profesjonalny sposób powinny podwoić wysiłki po to, aby wskazać Polakom, że przeszłość ma także ogromny wpływ na czasy współczesne oraz że na jej podstawie określamy własną tożsamość i kontekst życia w teraźniejszości.

\section{SPOŁECZNE ZAINTERESOWANIE ARCHEOLOGIĄ I STOSUNEK DO NIEJ}

Zagadnienia związane ze społecznym zainteresowaniem archeologią zostały zinterpretowane na podstawie odpowiedzi na pytania numer 10, 11, 14, 15 i 16. Pytanie numer 10 dotyczyło tego, co wydaje się respondentom interesujące $\mathrm{w}$ archeologii. I tak $40 \%$ z nich uznało, że to właśnie poznawanie własnej przeszłości jest czymś, co najbardziej pociąga w tej nauce, kolejne $40 \%$ stwierdziło, że odkrywanie nowych informacji o przeszłości jest czymś fascynującym. Tylko 3\% w tym przypadku wskazało na zainteresowanie eksploracją związaną z poszukiwaniem zabytków i historią jako wiedzą o przeszłości.

W przypadku pytania 11, które brzmiało „Gdybyś miał/a odwiedzić jakieś stanowisko archeologiczne albo wystawę, czego by to dotyczyło?”, większość ankietowanych (28\%) wskazywała, że najchętniej odwiedziliby stanowiska czy wystawy związane z okresem antycznym: greckim lub rzymskim. 25\% osób stwierdziło, że interesujący jest dla nich okres prehistoryczny, $23 \%$ respondentów wskazało na średniowiecze, $10 \%$ z nich zainteresowałoby się okresem współczesnym: I i II wojną światową. Interesujące jest to, że większość ludzi młodych w wieku od 18 do 24 lat wspominało o czasach współczesnych, z kolei średniowiecze i antyk przyciągały najstarszą grupę osób w wieku powyżej 60 lat.

\footnotetext{
${ }^{6}$ Średnia europejska odpowiedzi dla tego pytania wynosiła $44 \%$.
} 


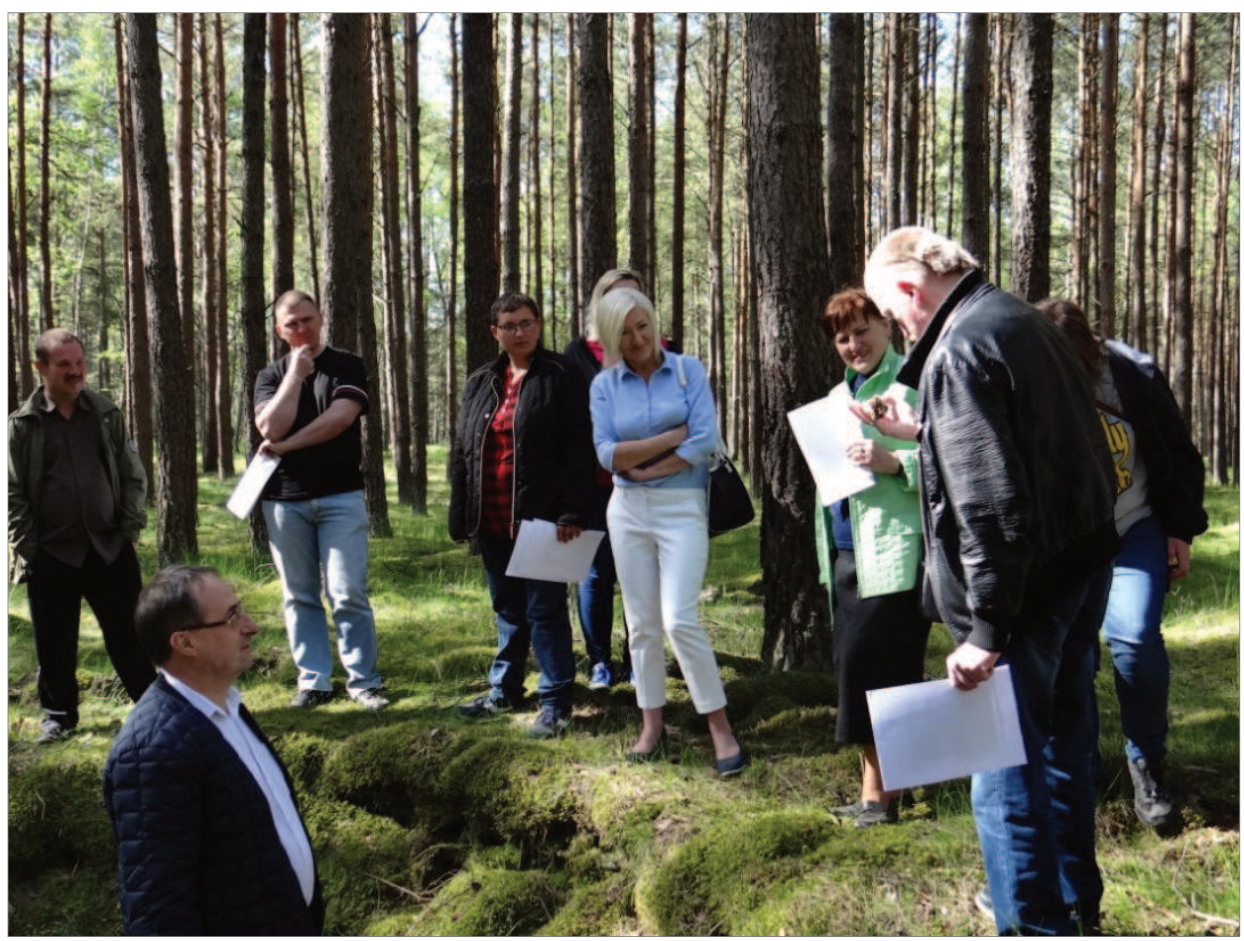

Ryc. 2. Lekcja „żywej archeologii” przeprowadzona dla grupy osób z niepełnosprawnościami intelektualnymi w ramach popularyzacji wiedzy archeologicznej wśród różnych grup (fot. Dawid Kobiałka)

Fig. 2. The lesson of ,archaeology-live” in which took part people with intellectual disabilities as a way to popularize archaeology among various groups of people (photo by Dawid Kobiałka)

W celu określenia stosunku do archeologii i dziedzictwa archeologicznego ankietowani w pytaniu 14 zostali poproszeni o zgodzenie lub niezgodzenie się z poniższą kwestią: „Posiadanie pozostałości archeologicznych może być pozytywne dla miasta". W tym przypadku aż $90 \%$ osób zgodziło się z tym stwierdzeniem, zaś $82 \%$ uznało także, że ,wspieranie i rozwijanie archeologii jest istotne dla Polski”. 81\% respondentów opowiadało się także za tezą, że „obywatel danego kraju powinien mieć jakąś wiedzę archeologiczną na jego temat”, 68\% ankietowanych wskazało, że ,archeologia jest dziedziną, która ich interesuje, i którą chcieliby zgłębić”. Mniej niż połowa respondentów (48\%) potwierdziła, że ,,archeologia powinna zostać dodana do przedmiotów szkolnych”, a 42\% zaznaczyło, że ,,archeologia jest dziedziną, w której ich dziecko mogłoby pracować” oraz 41\%, że ,archeologia jest dziedziną, z którą czują się związani”.

Zainteresowanie archeologią było także tematem pytania 15, w którym oczekiwano odpowiedzi, czy respondenci byliby zainteresowani bezpośrednim udziałem w przedsięwzięciach związanych z archeologią. Aż $82 \%$ osób stwierdziło, że chcia- 
łoby odwiedzić stanowisko archeologiczne, ale tylko 68\% uznało, że mogłoby wziąć udział w wydarzeniach związanych z archeologią. Dodatkowo $72 \%$ ankietowanych stwierdziło, że chciałoby spotkać się z archeologami, aby lepiej zrozumieć znaczenie ich pracy dla lokalnej społeczności, a $69 \%$, że spotkania z archeologami przybliżyłyby im samą profesję. Natomiast $57 \%$ respondentów wyraziło chęć bycia zaangażowanym $\mathrm{w}$ procesy decyzyjne związane $\mathrm{z}$ projektami archeologicznymi odbywającymi się w okolicy. Natomiast mniej niż połowa (36\%) uznała, że mogłaby mieć swój wkład w finansowaniu działań archeologów.

\section{SPOŁECZNE ROZUMIENIE I POSTRZEGANIE ARCHEOLOGICZNYCH BADAŃ RATUNKOWYCH}

W badaniu prowadzonym $w$ ramach projektu NEARCH został podjęty także temat związany $\mathrm{z}$ archeologią ratowniczą, będącą obecnie jednym $\mathrm{z}$ najbardziej społecznie rozpoznawalnych - z racji choćby natężenia tego typu działań - i namacalnych sposobów uprawiania archeologii. Społeczeństwo najczęściej słyszy o pracach archeologicznych wówczas, gdy są one prowadzone w związku z budową dróg, centrów handlowych czy w przypadku prywatnych inwestycji związanych z budową domów. W takich wypadkach archeologia ratownicza budzi duże kontrowersje społeczne, ponieważ z jednej strony uważana jest za coś potrzebnego, co ratuje przeszłe dziedzictwo od zniszczenia, z drugiej natomiast pojawia się wiele głosów mówiących o kosztowności takich prac i ich małym pożytku społecznym w stosunku do strat finansowych i czasowych, jakie ona za sobą pociągają. Pogodzenie tych dwóch stanowisk było i jest nadal bardzo trudne. Dlatego celem wywiadów było przyjrzenie się kwestii badań ratowniczych z perspektywy osób ankietowanych, co w przyszłości może pomóc $\mathrm{w}$ wypracowaniu dobrych praktyk w ramach współpracy i negocjacji archeologów z różnymi grupami zainteresowanych osób.

Pierwsze z pytań zadanych respondentom dotyczyło znajomości samego terminu „,archeologia ratownicza”. 50\% respondentów stwierdziło, że nie zna tego pojęcia, natomiast $36 \%$, że słyszało o nim, lecz nie wie, co ono oznacza. Zaledwie 13\% osób odpowiedziało, że zna ten termin i rozumie jego znaczenie. Mimo tak niskiego wyniku, na tle europejskim Polacy okazali się grupą, w której więcej osób niż w innych państwach zna pojęcie ,archeologia ratownicza”. W przypadku respondentów z innych państw europejskich zaledwie 10\% ankietowanych wiedziało, czym jest archeologia ratownicza, a nie więcej niż $25 \%$ w ogóle słyszało o tym terminie. Wśród Polaków najwięcej osób, które znały i rozumiały jego znaczenie, znajdowało się w grupie wiekowej od 25-34 i 35-44 lat, większość zaś z nich pochodziła z centralnej i południowo-zachodniej Polski. Najmniejszą znajomością tego pojęcia wykazała się najmłodsza grupa respondentów (18-24 lat) zamieszkująca północną część naszego kraju. 


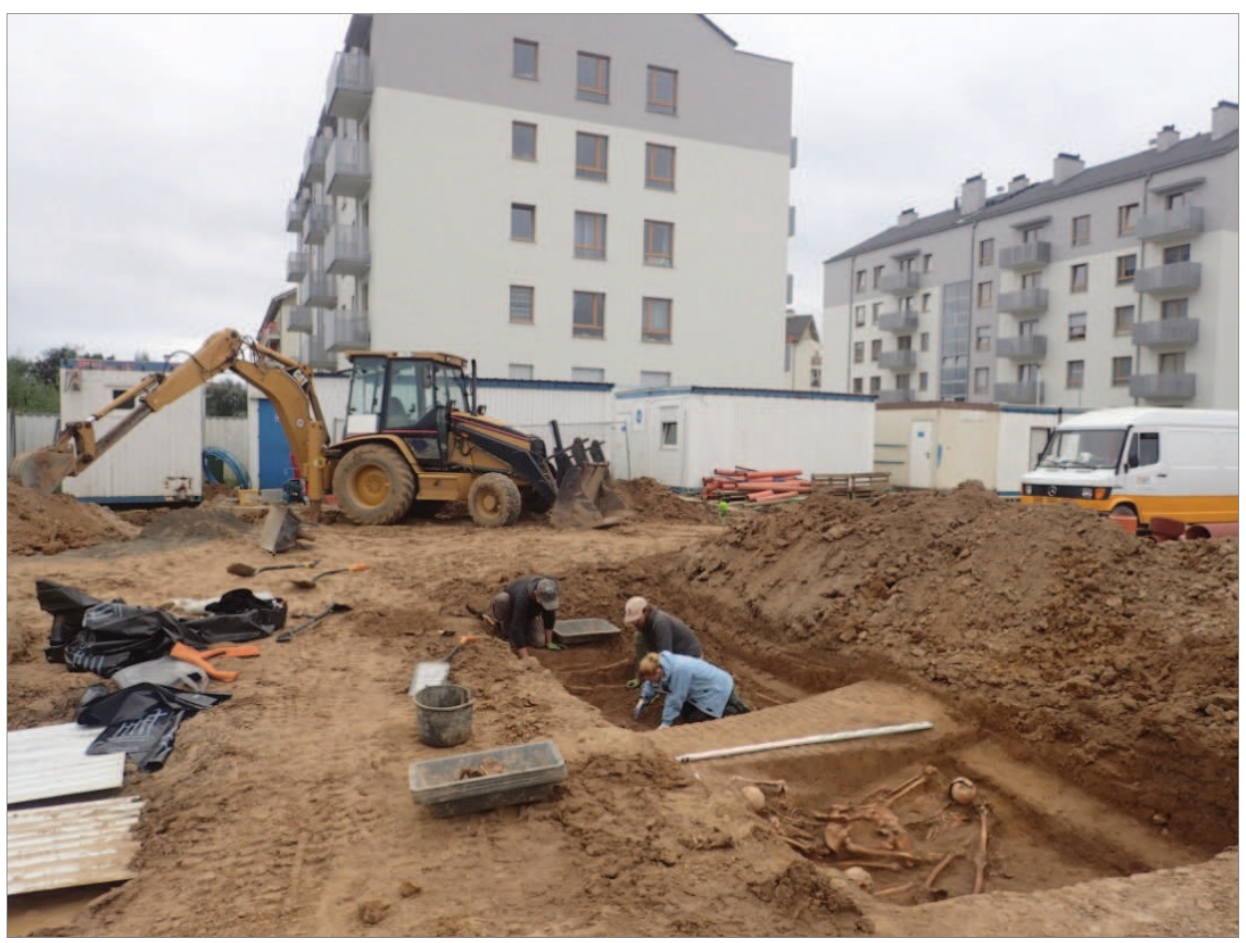

Ryc. 3. Prace ekshumacyjne prowadzone przez archeologów w trakcie budowy jednego z osiedli w Gorzowie Wielkopolskim (fot. Maksymilian Frąckowiak)

Fig. 3. Exhumation works conducted by archaeologists during construction of a residential area in Gorzów Wielkopolski (photo by Maksymilian Frąckowiak)

Pytanie numer 23 dotyczyło z kolei Europejskiej konwencji o ochronie dziedzictwa archeologicznego - tzw. „Konwencji Maltańskiej” z 1992 roku i jednego z jej zapisów dotyczącego ochrony dziedzictwa archeologicznego ${ }^{7}$. Ankietowani mieli zdecydować, czy uważają, że jest on istotny, czy też nie. Przeważająca większość respondentów (aż 93\%) uznała zapis o ochronie dziedzictwa archeologicznego za wartościowy. Tylko 5\% osób stwierdziło, że taki zapis nie niesie ze sobą nic dobrego, a $2 \%$ respondentów nie miało w tej kwestii zdania. Podobną wymowę miało pytanie 24, które dotyczyło możliwych konsekwencji wynikających z Konwencji Maltańskiej. Ankietowanych zapytano, czy ich zdaniem zobligowanie do przepro-

${ }^{7}$ W 1992 roku została podpisana i ratyfikowana przez 16 członków Konwencja Maltańska, która jest europejskim aktem prawnym mówiącym o ochronie dziedzictwa archeologicznego. Sygnatariusze zobowiązali się do stworzenia legislacji mającej na celu ochronę dziedzictwa archeologicznego oraz zagwarantowanie naukowości prac archeologicznych. Biorąc to pod uwagę, uważasz, że konwencja ta jest: a) dobrą rzeczą, b) niedobrą rzeczą, c) brak odpowiedzi. 
wadzenia prac archeologicznych przed wszelkimi pracami budowlanymi jest pozytywne, czy też negatywne. Wydaje się wręcz zaskakujące, że aż 91\% osób uznało, że byłoby to dobre, a zaledwie $8 \%$ odniosło się do tego w sposób negatywny, $1 \%$ respondentów nie miało w tej kwestii zdania. Pytanie 25 miało na celu uściślenie motywacji dotyczącej oceny pozytywnej lub negatywnej w pytaniu numer 24 . I tak większość osób (49\%), która pozytywnie odniosła się do kwestii przeprowadzania badań archeologicznych przed inwestycjami budowlanymi, swoją odpowiedź umotywowała w ten sposób, że badania takie uchronią dziedzictwo od zniszczenia; inne odpowiedzi dotyczyły znaczenia dziedzictwa dla przyszłych pokoleń i stąd potrzeby jego ochrony. Te osoby, które odniosły się do omawianej kwestii, krytycznie uznały, że prace archeologiczne są kosztowane i jedynie spowalniają inne projekty infrastrukturalne czy budowlane.

\section{ARCHEOLOGIA I SPOLECZEŃSTWO W POLSCE - KROK W PRZYSZŁOŚĆ...}

Z przedstawionych badań wynika, że archeologia jako nauka jest traktowana przez polskie społeczeństwo z dużym zainteresowaniem. Pokazuje to swoiste uprzywilejowanie, jakie mają archeolodzy w kontekście społecznej akceptacji prowadzonych przez nich badań, a także zrozumienia dla ich znaczenia. Inaczej niż w przypadku wielu nauk, do których ,zwykły” obywatel ma utrudniony dostęp, w przypadku archeologii to niejednokrotnie naukowcy wkraczają w przestrzenie na co dzień uważane za zwykłe, czasem nieistotne i rozpoczynają swoje działania w miejscach, w których (lub obok których) toczy się życie codzienne. Właśnie ta przestrzeń daje pracom archeologicznym duże możliwości w kontekście społecznej edukacji. Stąd przywilej ten niesie ze sobą także konkretne zobowiązania, którym jako archeolodzy musimy stawiać czoła. Oznacza to, że archeolodzy, w związku z tym, że są często bacznie obserwowani przez społeczeństwo, powinni także podejmować wszelkie możliwe działania, aby angażować w prowadzone przez siebie badania grupy zainteresowane ich pracami oraz wynikach badań. Dość aktualna w tym kontekście wydaje się uwaga wypowiedziana dwie dekady temu przez Stanisława Tabaczyńskiego (1997, s. 29-30), który wskazywał, że jedno z głównych wyzwań stojących przed archeologią polega na tym, że powinna ona „,sprostać nie tylko wymogom ścisłości naukowej, lecz także wyjść naprzeciw potrzebom i oczekiwaniom społecznym. Winna być społecznie akceptowana, budzić zainteresowanie i poczucie identyfikacji z deklarowanymi wartościami”.

$\mathrm{Z}$ przeprowadzanych badań wynika także to, co zostało już zaobserwowane przez Ewę Domańską (2006, s. 73) i Michała Pawletę (2016, s. 77), że społeczeństwo nie potrzebuje przeszłości w perspektywie całościowej, a raczej decyduje, które jej części są dla niego istotne i warte zainteresowania. Stąd też Polacy tak silnie 
podkreślali znaczenie i wartość poznawania własnej, lokalnej historii, wykazując się mniejszym zainteresowaniem w stosunku do historii innych państw europejskich. Owo zainteresowanie własną przeszłością może także wskazywać, że istotnym motywem poznawania historii jest dostrzeganie w przeszłości: „,fundamentu dla budowania wspólnej tożsamości i podstawy do samookreślenia się ludzi jako istot żyjących $\mathrm{w}$ pewnych wspólnotach. [...] odniesienia do przeszłości i wzmożone zainteresowanie nią mogą być związane z poszukiwaniem i definiowaniem indywidualnych bądź grupowych (istniejących lub wymyślonych) tożsamości, stanowić wyraz ich legitymizacji bądź afirmacji, a także obrony przed zagrożeniami z zewnątrz" (Pawleta, 2016, s. 77).

Zainteresowanie przeszłością nie wynika jedynie z tego, że społeczeństwo chce - opierając się na przeszłości - kreować i określać swoją tożsamość. Także warunki ekonomiczne oraz szanse, a niekiedy i zagrożenia dla rozwoju miejscowości, jakie niesie ze sobą ochrona dziedzictwa archeologicznego, stanowią istotny element, z powodu którego społeczeństwo wykazuje duże zainteresowanie tym, co się dzieje z przestrzeniami związanymi z przeszłością. Jak wynika z przedstawionych badań, duża część respondentów zaznaczała, że zdaje sobie sprawę z wartości dziedzictwa archeologicznego i jego pozytywnego znaczenia dla rozwoju miejscowości. Wynika zatem z tego, że społeczeństwo ma świadomość roli dziedzictwa kulturowego dla zrównoważonego rozwoju i jednocześnie domaga się także prawa do decydowania o tym, w jaki sposób prowadzone będą prace i jaki potencjalny wpływ będą miały one na rozwój lokalny. Archeolodzy poprzez swoje prace zawsze wkraczają w lokalny krajobraz kulturowy i naturalny i zmieniają jego dotychczasowy porządek, co może spotykać się zarówno z negatywnymi, jak i pozytywnymi reakcjami. Dlatego tak istotna jest współpraca i docenianie lokalnych społeczności i inicjatyw, a także wsłuchiwanie się w głosy osób na co dzień przebywających w pobliżu miejsc prac archeologów.

Choć wielu autorów wskazywało na to, że poznawanie przeszłości może wpływać na rozumienie procesów, jakie zachodzą w teraźniejszości (Kowalewski, 2007; Zalewska, 2013; Hamilakis, 2017), Polacy rzadko odnosili się do takiej roli przeszłości. Wśród respondentów znacząco dominowała perspektywa tworzenia tożsamości przez wspólną przeszłość, a znaczenie wydarzeń, które miały miejsce kilkaset lat temu, zgodnie z uzyskanymi odpowiedziami było raczej niewielkie. Być może wynika to $\mathrm{z}$ faktu, że w Polsce archeologia nadal kojarzona jest $\mathrm{z}$ bardzo odległą przeszłością, dotyczącą czasów prahistorycznych, a wszelkie działania archeologów związane z badaniami nad czasami współczesnymi są nadal uznawane za wyłączną domenę historii. Poszerzanie rozumienia archeologii o czasy najnowsze i wprowadzanie pojęcia archeologii współczesnej przeszłości, która postuluje poznawanie przeszłości w celu dotarcia do sensów teraźniejszości (por. Harrison, Schofield, 2010; González-Ruibal, 2013; Zalewska, 2013; Moshenska, 2015), obecnie dokonuje się w Polsce dopiero w świecie naukowym, trudno więc wymagać od społeczeństwa tak szerokiego spojrzenia na zakres pracy archeologów. 
Napisanie niniejszego artykułu było możliwe dzięki uczestnictwu w projekcie „NEARCH. New Ways of Community-Involved Archaeology” realizowanym w Instytucie Archeologii UAM w Poznaniu (2013-2018) ze środków Komisji Europejskiej. Odzwierciedla on wyłącznie stanowisko jego autorów, a Komisja Europejska nie ponosi odpowiedzialności za jakiekolwiek wykorzystanie zawartych w nim informacji [Although the article resulted from the project supported by the European Communion, it reflects the views of its authors, exclusively, and the Commission should not be held responsible for any use which may be made of information and opinion presented herein].

\section{BIBLIOGRAFIA}

Chowaniec R.

2010 Dziedzictwo archeologiczne w Polsce: formy edukacji i popularyzacji. Warszawa: Instytut Archeologii UW.

Chowaniec R., Więckowski W. (red.)

2012 Archaeological Heritage: Methods of Education and Popularization. Oxford: BAR.

Czopek S., Górki J. (red.)

2016 Między nauka a popularyzacją: muzea i parki archeologiczne. Kraków: Universitas.

Domańska E.

2006 O potrzebie przeszłości. W: D. Minta-Tworzowska, Ł. Olędzki (red.), Komu potrzebna jest przeszłość? (s. 72-83). Poznań: KNSA, Instytut Prahistorii UAM.

Czerniak L.

2011 Dla kogo są wykopaliska? Profesjonaliści i społeczeństwo. W: A. Marciniak, D. MintaTworzowska, M. Pawleta (red.), Współczesne oblicza przeszłości (s. 177-186). Poznań: Wydawnictwo Poznańskie.

Deskur K.

2009 Idea public archaeology - edukacja archeologiczna i popularyzacja archeologii. Fontes Archaeologici Posnanienses, 45, s. 283-292.

González-Ruibal A.

2013 Reclaiming Archaeology. W: A. González-Ruibal (red.), Reclaiming Archaeology. Beyond the Tropes of Modernity (s. 1-29). London: Routledge.

Hamilakis Y.

2017 Archaeologies of Forced and Undocumented Migration. Journal of Contemporary Archaeology, 3(2), s. 121-139.

Harrison R., Schofield J.

2010 After Modernity. Archaeological Approaches to the Contemporary Past. New York: Oxford University Press.

Kajda K., Kostyrko M.

2016 Contemporary Dimension of Heritage Promotion - Towards Socially Engaged Archaeology. Sprawozdania Archeologiczne, 68, s. 9-24.

Kajda K., Marx A., Pawleta M. i in.

2017 Archaeology, Heritage and Social Value. The Public Perspectives on European Archaeology. European Journal of Archaeology, 21(1), s. 1-22. 
Kobyliński Z., Paczuska A.

2007 Poglądy młodzieży liceów warszawskich na temat zabytków: czy teorie konserwatorskie są zgodne z oczekiwaniami społecznymi. Ochrona Zabytków, 2, s. 81-92.

Kowalewski J.

2007 O problemach ze społecznym zaangażowaniem historiografii. W: J. Kowalewski, W. Piasek (red.), Zaangażowanie czy izolacja. Wspótczesne strategie społecznej egzystencji humanistów (s. 109-129). Olsztyn: Instytut Filozofii Uniwersytetu Warmińsko-Mazurskiego.

Kot M.

2015 Badanie: dziedzictwo archeologiczne należy do... urzędników i naukowców. Pobrano z: http://naukawpolsce.pap.pl/aktualnosci/news\%2C404320\%2Cbadanie-dziedzictwo-arche ologiczne-nalezy-do-urzednikow-i-naukowcow.html [dostęp: 1.12.2017].

Kozioł A., Trelka M., Florjanowicz P.

2013 Społeczno-gospodarcze oddziaływanie dziedzictwa kulturowego. Raport z badań spotecznych. Warszawa: Narodowy Instytut Dziedzictwa.

Kubiatowski Z.

2015 Wiedza studentów archeologii z zakresu promocji i wykorzystania archeologii do rozwoju społecznego i gospodarczego. Materiaty i Sprawozdania Rzeszowskiego Ośrodka Archeologicznego, 34, s. 231-240.

Moshenska G.

2015 Curated Ruins and the Endurance of Conflict Heritage. Conservation and Management of Archaeological Sites, 17(1), s. 77-90.

Pawleta M.

2016 Przeszłość we wspótczesności. Studium metodologiczne archeologicznie kreowanej przeszłości w przestrzeni społecznej. Poznań: Wydawnictwo Naukowe UAM.

Tabaczyński S.

1997 Ochrona dziedzictwa archeologicznego w Polsce i jej konteksty. Przegląd problemów. W: Aktualne zagrożenia dziedzictwa archeologicznego. Materiały z Konferencji Ogólnopolskiej, Poznań 17 kwietnia 1997 r. (s. 26-30). Poznań: Muzeum Archeologiczne w Poznaniu.

Zalewska A.

2013 Relevant and Applied Archaeology. The Material Remains of the First World War: Between „Foundational” and „Biographical” Memory, Between „Black Archaeology” and „Conflict Archaeology”. Sprawozdania Archeologiczne, 65, s. 9-50.

\title{
ARCHAEOLOGY, ARCHAEOLOGICAL HERITAGE AND THEIR SOCIAL SIGNIFICANCE AMONG CONTEMPORARY POLES
}

\author{
S u m m a r y
}

The article presents and analyses the survey that was conducted in the Framework of the European project NEARCH. The survey aimed at studying the social perception and role of archaeology in nine European countries (Poland, Greece, Italy, France, Sweden, UK, Spain, Holland 
and Germany). It was conducted by Harris Interactive company. In this article we focus on the Polish part of the study and we take into account the responds of Polish people to get to know Poles' perspectives on many aspects connected to understanding on the role of archaeology in the everyday life. The survey was made up from 28 questions and some of them were profiled in such a way to correspond to the differences in the countries' cultures and histories and to make the interpretations of the questions more viable. The survey had a form of open and close questions and their interpretation was conducted according to the guide provided the Harris Interactive company.

In this article we decided to analyze and interpret only chosen parts of the survey conducted in Poland. There were three points of interest that are visible in the paper, these are: social understanding of archaeology, social interest in archaeology, and social understanding and interest in the so-called preventive, rescue archaeology.

In summary, the survey's results indicate that archaeology as a scientific discipline is treated with a special interest by the Polish society. It shows that archaeologists had a special privilege in the context of acceptance of their works and social understating of its importance. Unlike many other scientific disciplines which studies and results individuals cannot reach, archaeologists intervene in the landscapes and places that are perceived as everyday and normal and they start their projects in the spaces in which (or near which) the everyday life takes place. This special place taken by archaeologists gives them a unique opportunity to educate people, therefore archaeologists as not many other disciplines, should use this chance and cooperate with the society because, as it is shown in the survey, Polish society needs and wants it. 